\title{
Knowledge and vaccination status of hepatitis $B$ amongst medical interns of Rural Medical College, Loni, Maharashtra, India
}

\author{
Purushottam A. Giri ${ }^{1}$, Deepak B. Phalke ${ }^{2}$
}

${ }^{1}$ Associate Professor; ${ }^{2}$ Professor and Head; Department of Community Medicine (PSM), Rural Medical College and Pravara Rural Hospital, Loni Dist. Ahmednagar, Maharashtra, India.

\section{Abstract}

Hepatitis B Virus (HBV) infection is a serious global public health problem. It is the most common blood borne viral infection which places healthcare professional at higher occupational risk. The present study was conducted to assess the current knowledge and vaccination status about hepatitis B amongst medical interns. A cross-sectional study was conducted between February and March 2009 on 100 medical interns of the Rural Medical College, Loni, India. A pre-designed questionnaire which assessed their knowledge of hepatitis B was the tool of data collection. The data was analyzed in the form of percentage and proportions, and the chi-square test was applied. In the present study, $83.3 \%$ of interns showed a good level of knowledge regarding hepatitis B infection. The percentage of interns with the correct knowledge regarding post exposure prophylaxis and mode of transmission of hepatitis B were $89 \%$ and $90 \%$ respectively. It was found that $87 \%$ of the respondents espoused vaccination as a measure for the prevention of hepatitis B and $72 \%$ of the interns were fully immunized against hepatitis B. However, there is a misconception about prophylaxis, vaccination and the treatment of HBV. Hence there is an imperative need for health education to improve the knowledge of the interns towards hepatitis B infection.

Keywords: Knowledge, Vaccination status, Hepatitis B infection, Medical interns, rural India.

\section{Introduction}

Hepatitis B Virus (HBV) infection is a serious global public health problem. Worldwide, nearly two billion people have been acutely infected with HBV and there are nearly 350 million people have chronically infected. ${ }^{1}$ Of these 350 million, at least one million die annually from HBV-related chronic liver disease, including cirrhosis and liver cancer. However, the significance and magnitude of the problem vary from country to country. ${ }^{2}$ Throughout the world, millions of healthcare professionals work in health institutions and it is esteemed that $6,00,000$ to $8,00,000$ cut and puncture injuries occur among them per year. The annual proportion of healthcare workers exposed to blood borne pathogens was 5.9\% for $\mathrm{HBV}$, corresponding to about $66,000 \mathrm{HBV}$ infections in healthcare workers worldwide. ${ }^{3}$

In India it is the second most common cause for acute hepatitis. The prevalence of $\mathrm{HBV}$ infection ranges between $5-10 \%$ in South East Asian Region and 1\% in Northern Europe and America. ${ }^{3}$ In India, prevalence of HBV among general population varies from 2 to $8 \%$, and about three to four times greater in medical professionals and six times greater in non-immunized surgical specialties than that of general population. ${ }^{3} \mathrm{HBV}$ is a DNA virus classified in the virus family Hepadnaviridae. Humans are the only known natural host. HBV enters the liver via the bloodstream, and replication occurs only in liver tissue. ${ }^{4}$ To increase the awareness and knowledge about viral hepatitis, World Health Organization (WHO) has declared

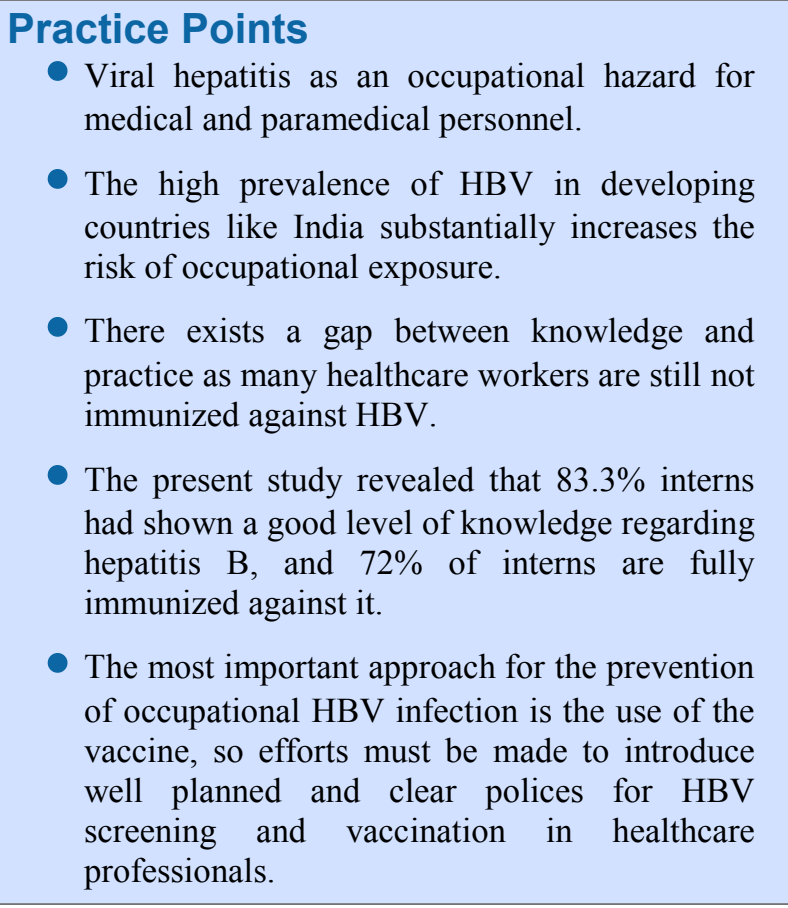

28th July as the World Hepatitis Day/Eradication day.

Medical interns were expected to have sufficient knowledge on the mode of transmission and treatment of HBV. Like other healthcare workers, interns are at a higher risk of acquiring HBV infection compared to the other population. ${ }^{3}$ A study conducted by Singh et

Correspondence: Dr. Purushottam A. Giri, Associate Professor, Dept. of Community Medicine (PSM), Rural Medical College of Pravara Institute of Medical Sciences, (Deemed University), Loni, Maharashtra, India. E-mail: drpgiri14@gmail.com. 
$a l .{ }^{5}$ concluded that there is a lack of awareness among the medical students entering into the profession about Hepatitis B, its route of transmission and modes of prevention. These interns represent the physicians who would graduate and practice medicine from next year. Therefore, they are expected to play an imperative role in limiting the increasing number of $\mathrm{HBV}$ infection cases and in promoting health education in India.

Hence the present study was carried out to assess the current knowledge regarding hepatitis $\mathrm{B}$ infection among medical interns of rural medical college, Loni, Maharashtra, India.

\section{Materials and Methods}

A cross-sectional study was carried out amongst interns of Rural Medical College, Loni, Maharashtra, India during the period between February to March 2009. All 100 interns of regular batch of 2009 year were enrolled, and given a briefing about the design and objectives of the study. The informed consent was obtained from each participant. Ethical approval was obtained from the institutional ethics committee.

The data were collected on a pre-designed, prestructured questionnaire distributed among these interns. The questionnaire was pretested on 20 interns, apart from study subjects and necessary changes were made accordingly. The questionnaire was in English and consisted of questions related to knowledge of hepatitis $\mathrm{B}$ infection as regards to basic information, epidemiological aspects and prevention related issues. All the questions were objective in nature with 'Yes' or 'No' as the options, although a few questions were of multiplechoice type. Knowledge was assessed through 12 questions. A scoring mechanism was used to understand overall knowledge level. Each correct answer was given one score, and the range of the score varied between 0 (with no correct answer) to 12 (for all correct answers). Respondents with all correct response get a maximum of 12 points; higher points indicate good knowledge. Based on total score, knowledge level was categorized into poor ( $\leq 4$ points), average (5-8 points), and good ( $\geq$ 9 points).

Demographic details like age, sex and marital status of the respondents were also recorded. Data were entered into Microsoft Excel and analyzed using the Statistical Package of Social Sciences (SPSS) version-13.0. Statistical significance was set at $p \leq 0.05$.

\section{Results}

The demographic characteristics and vaccination status of the study population was shown in Table 1 . Out of total 100 participants, $64 \%$ were males and $36 \%$ were females and only $12 \%$ were married. There were $31 \%$ and $39 \%$ participants in the age groups $22-23$ and $23-24$ years respectively and majority $72 \%$ of interns are fully immunized for hepatitis B.

The responses of the interns regarding their knowledge towards hepatitis B infection were depicted in Table 2. Majority (83.3\%) interns had shown good level of
Table 1: Demographic characteristics and vaccination status of the study population

\begin{tabular}{|l|c|}
\hline Particulars & Respondents* $^{*}$ \\
\hline Age (in years) & 28 \\
$21-22$ & 31 \\
$22-23$ & 39 \\
$23-24$ & 02 \\
Above 24 & 64 \\
\hline Gender & 36 \\
Male & \\
Female & 12 \\
\hline Marital status & 88 \\
Married & \\
Unmarried & 72 \\
\hline Vaccination status & 18 \\
Yes & \\
No & \\
\hline
\end{tabular}

*Data indicates both number and percentage

knowledge, whereas $16.6 \%$ had average level of knowledge. Ninety percentages of interns had correct knowledge regarding mode of transmission. However, only $35 \%$ interns could know about hepatitis B virus is a member of the hepadnavirus family. When asks the question like 'Immunity after receiving hepatitis B vaccination lasts lifelong', the more than half i.e. 51\% interns couldn't gave the correct answer $(\mathrm{p}<0.05)$. Vaccination as a measure to prevent hepatitis B infection was espoused by $87 \%$ of the respondents. Although hepatitis B vaccination was included in national immunization program in India, but it is surprising that $30 \%$ interns are not aware of the program and even $27 \%$ interns didn't know the correct WHO schedule for hepatitis B immunization $(\mathrm{p}<0.05)$.

\section{Discussion}

Hepatitis B virus infection is considered as a serious health problem in the developing countries since it causes chronic liver cirrhosis and hepatocellular carcinoma. ${ }^{6} \mathrm{HBV}$ infection is an occupational risk for physicians and surgeons especially in developing countries where a carrier rate is about $4 \%$ and kills about 1.1 million people globally every year. ${ }^{7}$ The present study revealed that $83.3 \%$ interns had shown good level of knowledge, whereas $16.6 \%$ had average level of knowledge. This may be attributed to coverage of topic in undergraduate curriculum and further reinforcement on universal precaution during internship training program. Similar findings by Khan et $a l^{8}$ and Magdy et $a l^{9}{ }^{9}$ reported that, the overall knowledge level regarding hepatitis B among medical students, ranged between 'good' to 'average'.

Majority $90 \%$ of interns had correct knowledge regarding mode of transmission of hepatitis $\mathrm{B}$ in the present study. Similar findings by Magdy et al. ${ }^{9}$ and Singh et al. ${ }^{5}$ among medical students, revealed that $77.7 \%$ and $86.7 \%$ of students had correct knowledge regarding mode of transmission of hepatitis B respectively. Another study done by Kasetty et al..$^{10}$ among dental professionals, showed that $82.1 \%$ had correct 
Table 2: Gender wise distribution of respondent's knowledge about HBV infection

\begin{tabular}{|c|c|c|c|c|c|c|c|}
\hline \multirow[t]{2}{*}{ Questions regarding knowledge } & \multicolumn{3}{|c|}{ Correct answer $^{\dagger}$} & \multicolumn{3}{|c|}{ Incorrect answer $^{\dagger}$} & \multirow{2}{*}{$\begin{array}{l}\chi^{2} \text {-value } \\
p \text {-value }\end{array}$} \\
\hline & Male & Female & Total & Male & Female & Total & \\
\hline $\begin{array}{l}\text { Is Hepatitis B virus is a member of hepadnavirus } \\
\text { family? (Yes)* }\end{array}$ & 25 & 10 & 35 & 39 & 26 & 65 & $\begin{array}{l}\chi^{2}=1.289 \\
p=0.256\end{array}$ \\
\hline $\begin{array}{l}\text { Is Hepatitis B infection preventable by vaccina- } \\
\text { tion? (Yes)* }\end{array}$ & 54 & 33 & 87 & 10 & 03 & 13 & $\begin{array}{l}\chi^{2}=0.53 \\
p=0.46\end{array}$ \\
\hline $\begin{array}{l}\text { Was Hepatitis B infection originally known as } \\
\text { serum hepatitis? (Yes)* }\end{array}$ & 53 & 32 & 85 & 11 & 04 & 15 & $\begin{array}{l}\chi^{2}=0.28 \\
p=0.60\end{array}$ \\
\hline $\begin{array}{l}\text { What is the mode of transmission of Hepatitis B } \\
\text { virus infection? (Sexual \& parental)* }\end{array}$ & 57 & 33 & 90 & 07 & 03 & 10 & $\begin{array}{l}\chi^{2}=0.00 \\
p=0.94\end{array}$ \\
\hline $\begin{array}{l}\text { Who remain HBsAg positive for at least } 6 \text { months } \\
\text { are considered to be hepatitis B carriers? (Yes)* }\end{array}$ & 51 & 27 & 78 & 13 & 09 & 22 & $\begin{array}{l}\chi^{2}=0.295 \\
p=0.587\end{array}$ \\
\hline $\begin{array}{l}\text { Is transmission percentage higher after needle } \\
\text { stick for HBV in comparison with HIV? (Yes)* }\end{array}$ & 51 & 23 & 74 & 13 & 13 & 26 & $\begin{array}{l}\chi^{2}=2.988 \\
p=0.083\end{array}$ \\
\hline $\begin{array}{l}\text { Do you know about post exposure prophylaxis } \\
\text { (PEP) about Hepatitis B? (Hepatitis B vaccine \& } \\
\text { Hepatitis B immunoglobulin)* }\end{array}$ & 58 & 31 & 89 & 06 & 05 & 11 & $\begin{array}{l}\chi^{2}=0.479 \\
p=0.488\end{array}$ \\
\hline $\begin{array}{l}\text { Is hepatitis-B vaccination included in national } \\
\text { immunization program? (Yes)* }\end{array}$ & 48 & 22 & 70 & 16 & 14 & 30 & $\begin{array}{l}\chi^{2}=5.116 \\
p=0.045\end{array}$ \\
\hline $\begin{array}{l}\text { Is immunity after receiving hepatitis B vaccina- } \\
\text { tion lasts life long? (No)* }\end{array}$ & 26 & 23 & 49 & 38 & 13 & 51 & $\begin{array}{l}\chi^{2}=4.989 \\
p=0.025\end{array}$ \\
\hline $\begin{array}{l}\text { Do you know the correct WHO schedule for } \\
\text { Hepatitis B immunization? }(0,1 \& 6 \text { months fol- } \\
\text { lowed by } 1 \text { booster dose after } 5 \text { yrs })^{*}\end{array}$ & 53 & 20 & 73 & 11 & 16 & 27 & $\begin{array}{l}\chi^{2}=8.684 \\
p=0.003\end{array}$ \\
\hline $\begin{array}{l}\text { Do you think all patients undergoing major sur- } \\
\text { geries should be investigated for HBV? (Yes)* }\end{array}$ & 49 & 22 & 71 & 15 & 14 & 29 & $\begin{array}{l}\chi^{2}=2.671 \\
p=0.102\end{array}$ \\
\hline $\begin{array}{l}\text { Do you think medical personnel infected with } \\
\text { hepatitis B should avoid patient care/treatment? } \\
\text { (Yes)* }\end{array}$ & 53 & 31 & 86 & 11 & 05 & 14 & $\begin{array}{l}\chi^{2}=0.186 \\
p=0.605\end{array}$ \\
\hline
\end{tabular}

${ }^{\dagger}$ Data indicates both number and percentage; *Correct answers; $\$$ Values are significant $p<0.05$.

knowledge regarding the mode of transmission. Whereas a study done by Khan et al. ${ }^{8}$ among medical students of Karachi, found that only $57.1 \%$ had correct knowledge regarding the same.

In the present study, $89 \%$ interns had the correct knowledge regarding post exposure prophylaxis (PEP) for hepatitis B. Similarly a study by Kasetty et al. ${ }^{10}$ found that $93.9 \%$ dental professionals had correct knowledge regarding post exposure prophylaxis. However, in contrast, a study done by Khan et al. ${ }^{8}$ revealed that $76 \%$ medical students did not have the knowledge regarding post exposure prophylaxis. Low level of knowledge about post exposure treatment for hepatitis B among the medical students was also revealed by Magdy et al. ${ }^{9}$ Whereas a study done by Singh et al..$^{5}$ found that majority of third year undergraduate medical students gave correct answers, while only $20 \%$ of the second year had the correct knowledge regarding the same.

The most effective means to prevent HBV infection is through vaccination. Fortunately, infective hepatitis B is largely preventable disease by hepatitis B vaccine which is $95 \%$ effective in preventing such disease and its chronic consequences. ${ }^{11}$ In our study, vaccination as a measure to prevent hepatitis B infection was espoused by $87 \%$ of the respondents. Similarly a study by Singh et $a .^{5}$ also revealed that final year medical students had better knowledge regarding prevention of $\mathrm{HBV}$ as compared to first year students.

Prevention is ultimately the most efficient and humane means toward improved health. Viral hepatitis is preventable with effective vaccines, which is available since 1982 and have proven safe to both adults and children. ${ }^{12}$ In the present study, majority $72 \%$ of interns are fully immunized for hepatitis-B. The proportion of male and female interns completely vaccinated with three doses of hepatitis B vaccine was 51/64 (79.7\%) and $21 / 36(58.3 \%)$ respectively. However $28 \%$ of interns not immunized is the matter of concern. This is area showing knowledge application gap. They need further reinforcement in this matter. Similar results were observed in other studies also. ${ }^{5,8}$ However, in contrast, a study conducted by Magdy et al. ${ }^{9}$ revealed that only $28.1 \%$ of medical students were vaccinated against HBV. Since medical interns are at increased risk of acquiring needle stick injury and increased prevalence rate of hepatitis B in India, interns should be routinely vaccinated upon entry into the medical college.

The overall knowledge amongst medical interns were satisfactory as compared to other studies but there was a 
gap which needs to be corrected regarding inclusion of hepatitis $\mathrm{B}$ vaccination in national immunization program and even the correct WHO schedule for immunization, prevention and post-exposure management of hepatitis B. Therefore there is an essential need for continuing education among the interns to improve and update their knowledge about HBV infection.

This cross-sectional study was conducted amongst certain group of population i.e. medical interns only; therefore the findings cannot be generalized to all the interns or other healthcare professional in the country.

\section{Conclusion}

Hepatitis B is the most common blood borne viral infection which places healthcare professional at higher occupational risk. High prevalence of $\mathrm{HBV}$ in India substantially increases the risk of exposure to the virus. The present study revealed that $83.3 \%$ interns had shown good level of knowledge regarding hepatitis-B, and $72 \%$ of interns are fully immunized for the same, however $28 \%$ were not immunized which is matter of concern. Appropriate knowledge should be provided to the medical and other health care professional students regarding $\mathrm{HBV}$ in the curriculum.

Most important approach for prevention of occupational HBV infection is the use of hepatitis B vaccine, so efforts must be made to introduce well planned and clear polices for HBV screening and vaccination in healthcare professionals. Emphasis on mandatory vaccination policy, including the topic in internship orientation program will help to reduce the transmission of hepatitis B in healthcare settings.

\section{Acknowledgement}

We express our deep sense of gratitude to the Management, Pravara Medical Trust and the Principal, Rural Medical College Loni, Maharashtra, India. We also acknowledge the help and support of medical interns - Mabel Bishnoi and Kusum Lata during data collection.

\section{References}

1. Lee WM. Hepatitis B virus infection. $N$ Engl $J$ Med 1997; 337:1733-45.

2. Shepard CW, Simard EP, Finelli L, Fiore AE,
Bell BP. Hepatitis B virus infection: epidemiology and vaccination. Epidemiol Rev 2006; 28:112-25.

3. Singhal V, Bora D, Singh S. Hepatitis B in Healthcare Workers: Indian Scenario. J Lab Physicians 2009;1(2):41-8.

4. Lok AS, McMahon BJ. Chronic Hepatitis B. Hepatology 2007;34:507-39.

5. Singh A, Jain S. Prevention of Hepatitis B; knowledge and practices among Medical students. Healthline 2011; 2(2):8-11.

6. World Health Organization (WHO). Hepatitis B Fact Sheet No. 204. http://www.who.int/ mediacentre/factsheets/fs204/en/ (accessed Dec 2013).

7. Sarin SK, Singal AK, Tandon BN. Dimensions and issues of HBV control in India. $1^{\text {st }}$ ed. New Delhi: CBS Publishers, 1996:1- 4.

8. Khan N, Ahmed SM, Khalid MM, Siddiqui SH, Merchant AA. Effect of gender and age on the knowledge, attitude and practice regarding Hepatitis B and C and vaccination status of Hepatitis B among medical students of Karachi, Pakistan. J Pak Med Assoc 2010; 60(6):450-5.

9. Magdy A. Darwish and Nuha M. Al Khaldi. Knowledge about Hepatitis B Virus Infection among Medical Students in University of Dammam, Eastern Region of Saudi Arabia. Life Sci J 2013; 10(2):860-7.

10. Kasetty S, Mohania A, Dwivedi D, Tijare M, Kallianpur S and Gupta S. A Cross-Sectional Study on the Knowledge of Hepatitis B Infection among Dental Professionals. J Virology Microbiol 2013, Article ID 288280, DOI: $10.5171 / 2013.288280$.

11. World Health Organization (WHO): Immunization, Vaccines and Biologicals, hepatitis B. http:// www.who.int/immunization/topics/hepatitis b/en/ index.htm (accessed Dec 2013)

12. Ehreth J. The value of vaccination: A global perspective. Vaccine 2003;21:4105-17. 